\title{
Reply to 'Comment on 'Distinct clinical outcomes of two CIMP-positive colorectal cancer subtypes based on a revised CIMP classification system'"
}

Jeong Mo Bae ${ }^{1,2}$, Jung Ho Kim ${ }^{1,3}$, Yoonjin Kwak ${ }^{3,4}$, Dae-Won Lee ${ }^{5}$, Yongjun Cha ${ }^{5}$, Xianyu Wen ${ }^{1}$, Tae Hun Lee ${ }^{1}$, Nam-Yun Cho ${ }^{1}$ Seung-Yong Jeong ${ }^{6}$, Kyu Joo Park ${ }^{6}$, Sae Won Han ${ }^{5}$, Hye Seung Lee ${ }^{3,4}$, Tae-You Kim ${ }^{5}$ and Gyeong Hoon Kang ${ }^{\star}, 1,3$

${ }^{1}$ Laboratory of Epigenetics, Cancer Research Institute, Seoul National University College of Medicine, Seoul 03080, South Korea; ${ }^{2}$ Department of Pathology, SMG-SNU Boramae Medical Center, Seoul 07061, South Korea; ${ }^{3}$ Department of Pathology, Seoul National University College of Medicine, Seoul 03080, South Korea; ${ }^{4}$ Department of Pathology, Seoul National University Bundang Hospital, Seongnam 13620, South Korea; ${ }^{5}$ Department of Internal Medicine, Seoul National University Hospital, Seoul 03080, South Korea and ${ }^{6}$ Department of Surgery, Seoul National University Hospital, Seoul 03080, South Korea

Sir,

We thank Tapial et al, 2017 for their interest in our recent study. The authors applied our revised CIMP classification to their three different clinical data sets, which are composed of patients with early-onset colorectal cancer (EOCRC) (younger than 45 years), patients with late-onset CRC (LOCRC) (older than 70 years), and individuals diagnosed with synchronous CRC (SCRC). They addressed that only LOCRC cases showed similar tendency of increasing BRAF mutation, MSI-high and $\mathrm{MLH1}$ methylation along with the increase in the number of methylated genes. Moreover, they insisted that prognostic results were only partially confirmed in SCRC

Non-linearity of molecular alterations including $B R A F$ mutation, MSIhigh and MLH1 methylation in EOCRC and SCRC might originate from two reasons. First, EOCRC and SCRC have strong germline predispositions to $\mathrm{CRC}$, even though they are not either familial adenomatous polyposis or Lynch syndrome (Cybulski et al, 2014; de Voer et al, 2016). Recent studies revealed that germline predisposition in EOCRC is greater than expected (Pearlman et al, 2017); these germline predispositions are mainly associated with chromosomal instability rather than CIMP (Chan et al, 2001; McGivern et al, 2004). Second, CIMP-P2 CRCs usually occur in elderly patients. Two recent studies showed similar tendency in CRCs with BRAF mutation and concurrent MSI or MLH1 methylation (Seppala et al, 2015; Vedeld et al, 2017).

The authors tried to validate prognostic value of our revised CIMP classification in their EOCRC, LOCRC and SCRC subgroups. However, considering their previous publication, the sample size of each subgroup is too small to get enough statistical power for the subgroup of low prevalence, such as CIMP-P1 and CIMP-P2 (Ogino et al, 2011; Perea et al, 2015; Arriba et al, 2017). Considering the low prevalence of EOCRC and SCRC, a multi-centre study might be necessary to validate the prognostic value of our revised CIMP classification.

Overall, Tapial et al's results emphasise the fact that EOCRC and SCRC have different molecular landscapes compared with sporadic CRCs. Further comprehensive study might shed light on the complex interaction between germline predisposition, accumulation of somatic mutation and epigenetic alteration.

\section{CONFLICT OF INTEREST}

The authors declare no conflict of interest.

\section{REFERENCES}

Arriba M, Sanchez R, Rueda D, Gomez L, Garcia JL, Rodriguez Y, Pajares JA, Perez J, Urioste M, Sarmiento RG, Perea J (2017) Toward a molecular classification of synchronous colorectal cancer: clinical and molecular characterization. Clin Colorectal Cancer 16(1): 31-37.

Chan TL, Curtis LC, Leung SY, Farrington SM, Ho JW, Chan AS, Lam PW, Tse CW, Dunlop MG, Wyllie AH, Yuen ST (2001) Early-onset colorectal cancer with stable microsatellite DNA and near-diploid chromosomes. Oncogene 20(35): 4871-4876.

Cybulski C, Nazarali S, Narod SA (2014) Multiple primary cancers as a guide to heritability. Int J Cancer 135(8): 1756-1763.

de Voer RM, Hahn MM, Weren RD, Mensenkamp AR, Gilissen C, van Zelst-Stams WA Spruijt L, Kets CM, Zhang J, Venselaar H, Vreede L, Schubert N, Tychon M, Derks R, Schackert HK, Geurts van Kessel A, Hoogerbrugge N, Ligtenberg MJ, Kuiper RP (2016) Identification of novel candidate genes for early-onset colorectal cancer susceptibility. PLoS Genet 12(2): e1005880.

McGivern A, Wynter CV, Whitehall VL, Kambara T, Spring KJ, Walsh MD, Barker MA, Arnold S, Simms LA, Leggett BA, Young J, Jass JR (2004) Promoter hypermethylation frequency and BRAF mutations distinguish hereditary non-polyposis colon cancer from sporadic MSI-H colon cancer. Fam Cancer 3(2): 101-107.

Ogino S, Chan AT, Fuchs CS, Giovannucci E (2011) Molecular pathological epidemiology of colorectal neoplasia: an emerging transdisciplinary and interdisciplinary field. Gut 60(3): 397-411.

Pearlman R, Frankel WL, Swanson B, Zhao W, Yilmaz A, Miller K, Bacher J, Bigley C Nelsen L, Goodfellow PJ, Goldberg RM, Paskett E, Shields PG, Freudenheim JL, Stanich PP, Lattimer I, Arnold M, Liyanarachchi S, Kalady M, Heald B, Greenwood C, Paquette I, Prues M, Draper DJ, Lindeman C, Kuebler JP, Reynolds K, Brell JM, Shaper AA, Mahesh S, Buie N, Weeman K, Shine K, Haut M, Edwards J, Bastola S, Wickham K, Khanduja KS, Zacks R, Pritchard CC, Shirts BH, Jacobson A, Allen B, de la Chapelle A, Hampel H (2017) Prevalence and Spectrum of germline cancer susceptibility gene mutations among patients with early-onset colorectal cancer. JAMA Oncol 3(4): 464-471.

Perea J, Cano JM, Rueda D, Garcia JL, Inglada L, Osorio I, Arriba M, Perez J, Gaspar M, Fernandez-Miguel T, Rodriguez Y, Benitez J, Gonzalez-Sarmiento R, Urioste M (2015) Classifying early-onset colorectal cancer according to tumor location: new potential subcategories to explore. Am J Cancer Res 5(7): 2308-2313.

Seppala TT, Bohm JP, Friman M, Lahtinen L, Vayrynen VM, Liipo TK, Ristimaki AP, Kairaluoma MV, Kellokumpu IH, Kuopio TH, Mecklin JP (2015) Combination of microsatellite instability and BRAF mutation status for subtyping colorectal cancer. Br J Cancer 112(12): 1966-1975.

Tapial S, Rueda D, Arriba M, Garcia JL, Brandariz L, Perez J, Rodriguez Y, GarciaOlmo D, Gonzalez-Sarmiento R, Urioste M, Perea J (2017) Comment on 'Distinct clinical outomes of two CIMP-positive colorectal cancer subtypes based on a revised CIMP classification system'. Br J Cancer; e-pub ahead of print 2 January 2018; doi:10.1038/bjc.2017.343.

Vedeld HM, Merok M, Jeanmougin M, Danielsen SA, Honne H, Presthus GK, Svindland A, Sjo OH, Hektoen M, Eknaes M, Nesbakken A, Lothe RA, Lind GE (2017) CpG island methylator phenotype identifies high risk patients among microsatellite stable BRAF mutated colorectal cancers. Int J Cancer 141(5): 967-976.

This work is published under the BJC's standard license to publish agreement After 12 months the license terms will change to a Creative Commons AttributionNonCommercial-Share Alike 4.0 Unported License. 